\title{
OVERVIEW OF THE RIVER BASIN MANAGEMENT PLANS IN THE BALTIC REGION UNDER THE WATERPRAXIS PROJECT
}

\author{
Māris Mednis ${ }^{1}$, Ivars Matisovs' ${ }^{2}, \bar{E}^{2}$ ika Teirumnieka ${ }^{2}$, \\ Andris Martinovs ${ }^{2}$, Gundars Valğgis ${ }^{2}$ \\ 1- Administrative District Court \\ Antonijas iela 6, Riga, Latvia \\ Ph.: +(371)29679368, e-mail: mmednis@inbox.lv \\ 2- Rezekne Higher Education Institution
}

90 Atbrivoshanas al., Rezekne, LV 4601, Latvia; ph.: +(371)64625167

\begin{abstract}
The paper provides brief overview of the river basin district management plans in the Baltic region within the WATERPRAXIS project, linked to the EU Water Framework Directive. Latvian experience in completion of the river basin district management plans is emphasized comparing to other regional cooperation partners. Article is based on the report documents, analysis of the available data and review of the development projects subject to implementation. To some extent also potential issues for discussion are outlined. Certain Baltic countries have had difficulties complying with the EU Water Framework Directive, and there are some potential areas of contention, which should be taken into account in further activities. In course of the administrative and territorial reform and compliance with other EU directives (e.g. in the renewable energy sector) modifications can be made to the status of spatial and also river basin management plans and for the purpose of sustainable development in the region.
\end{abstract}

Keywords: river basin management plans, Baltic region, WATERPRAXIS, public involvement.

\section{Introduction}

One of the most serious problems seen in the Baltic Sea is the eutrophication caused by nutrient loads. Practical measures have been taken to restrict them including development of the river basin management plans both on the EU and regional levels.

The study provides overview on formation of the river basin management plans in Latvia along with several other EU member states, namely, in terms of recognition of solutions to facilitate the review and the revision of planning documents under the EU Water Framework Directive and with emphasis on the project WATERPRAXIS in the Baltic region.

The following elements have been analyzed: structure of the competent authorities and coordinating bodies and their internal and external connections; participation and the role of the public and the interested parties in planning decision-making process; way to integrate and incorporate the objectives of environmental, economic and social policy of the country and region into the river basin water management plans.

The study allows the comparison of certain aspects of the existing management system in Latvia and the water resources management with similar systems operating in other European Union member states of the region.

\section{Materials and methods}

River basic district management planning and analysis is a complex multidimensional process, hence its analysis requires an integrated approach, involving use of various types of information sources.

First these are normative and planning documents, including legislation, government reports and policy papers, which determine development of areas at different scales.

Second, information that defines processes and trends of development for the river basic district management.

Third, website information from relevant government agencies and fora is mainly used. 
Fourth, telephone interviews according to given framework.

Valuable data have been obtained from reports of practitioners and plans elaborated within the WATERPRAXIS and the EU Water Framework Directive structures, such as reports and plans for Denmark, Germany, Finland, Poland, Lithuania, Sweden and Latvia.

\section{Water Framework Directive}

\section{Results and discussion}

On 23 October 2000, the Directive 2000/60/EC of the European Parliament and of the Council establishing a framework for the Community action in the field of water policy or, in short, the EU Water Framework Directive (or even shorter the WFD) was adopted [1].

Some of the key aims of the Water Framework Directive are: expanding the scope of water protection to all waters, surface waters and groundwater; achieving "good status" for all waters by a set deadline; water management based on river basins; "combined approach" of emission limit values and quality standards; getting the citizen involved more closely [2].

The WFD requires achievement of the following environmental objectives by 2015: good ecological/chemical status of surface water bodies, good ecological potential and chemical status, good chemical/quantitative status of groundwater bodies.

WFD as a tool for performance of its assignment prescribes the river basin management plans (hereafter abbreviated as RBMP) or river basin district management plans (hereafter abbreviated as RBDMP), also procedure for development of the plans and information to be included therein. The review and the revision of the planning documents under the WFD should take place until 22 December 2015, and thereafter every six years.

Development of management plan for each river basin district (hereafter abbreviated as RBD) is assigned by national laws, however the implementation of river basin restoration measures as envisaged in the WFD have had some deficiencies. For instance, in June 2010, Denmark, Lithuania and Poland were among twelve Member States receiving a European Commission written warning for failing to submit plans for managing Europe's river basins as required by the Water Framework Directive [3].

\section{The WATERPRAXIS project}

The project WATERPRAXIS "From theory and plans to eco-efficient and sustainable practices to improve the status of the Baltic Sea" partly funded by the Interreg IVB Baltic Sea Region Programme 2007-2013 aims to improve particularly the status of the Baltic Sea by assisting the implementation of river basin management plans into practice in the Baltic Sea region. The main idea of WATERPRAXIS is that by better understanding the problems and constraints, long-term solutions and concrete pilot investments may be identified. The project partnership consists of research organisations, universities, local authorities and NGOs from Denmark, Finland, Germany, Latvia, Lithuania, Poland and Sweden. WATERPRAXIS is based on the Interreg IIIB project "Watersketch" (2004-2007) [4] as practical implementation and expansion of the initial design.

Within the WATERPRAXIS work structure WP3 stands for: Reviewing River Basin Management, Plans and Processes. River basin management plans (RBMP) from various countries are selected for analysis and the main focus is set on their expected impacts on the status of Baltic Sea. Tasks of the WP3 are: critical analysis of the implementation plan of the RBMPs; analysis of the planning process; analysis of implementation platforms and procedures and identification of critical issues for practical policy integration with policy areas of specific regional relevance [5].

A number of WATERPRAXIS criteria themes and criteria were selected until the meeting in Roskilde, 23-24 June, 2009. Subsequently, partners have selected the River Basin Districts to be enclosed in the WP3 analyses (initially without the Daugava RBD) [6]. 


\section{Brief history of the Daugava RBMP development}

Daugava River District Advisory Board was established in 2006. Public discussion of the Daugava River Area Management Plan was held from 22 December 2008 to 22 June 2009. Final version of the Daugava river basin district management plan was approved by Order No. 474 of the Minister of Environment on 21 December 2009. The Plan and program of activities included therein should ensure attainment of environmental quality objectives in the Latvian surface waters and groundwater. The principal objective of the Plan shall be to prevent deterioration of condition of the waters and to improve the surface waters and groundwater in order all the said to be in a good condition until 2015. General objectives for Daugava RBD follow WFD directive.

Analysis of the Daugava RBDMP was introduced into the WATERPRAXIS framework after the initial list compiled by Denmark, Finland, Germany, Lithuania, Poland and Sweden.

Table.

Summary table of River Basin District Management Plans for Analysis [7]

(amended with inclusion of the Daugava RBD)

\begin{tabular}{|l|l|}
\hline Partner country & \multicolumn{1}{|c|}{ Selected river basin district } \\
\hline Denmark & Zealand River Basin District \\
\hline Finland & Oulujoki-Iijoki River Basin District \\
\hline Germany & $\begin{array}{l}\text { Oder River Basin District (actually transnational RBD of three EU member } \\
\text { states: Poland, Germany and Czech Republic [9]) }\end{array}$ \\
\hline Latvia & Daugava River Basin District \\
\hline Lithuania & Nemunas River Basin District \\
\hline Poland & Vistula River Basin District \\
\hline Sweden & River Basin District of Bottenviken (aka Norrbotten) \\
\hline
\end{tabular}

\section{Description of the RBM planning structure}

Outlines of the structure of RBM planning include hierarchical structure and levels, as well as key actors involved in RBMP classified as competent authorities and coordinating bodies.

Number of competent authorities responsible for RBD within different countries varies a lot since diversity should be taken into account in the planning and execution of measures; integration of water management into other policy areas such as energy, transport, agriculture, fisheries, regional policy and tourism is necessary; WFD should contribute to cooperation between memberstates [9].

In order to coordinate preparation and implementation of the river basin management plans and programs of measures, advisory boards were established for each RBD. These boards were designed to function as advisory mechanisms for the involvement of all - not only governmental - institutions and organizations concerned with the preparation and implementation of river basin management plans.

In Latvia Ministry of the Environment (present Ministry of Environment and Regional Development, hereafter abbreviated as MoEn) is responsible for RBD administration in Latvia. State limited liability company "Latvian Environment, Geology and Meteorology Centre" (hereafter abbreviated as LEGMC), subordinated to the MoEn is responsible for RBD monitoring in Latvia. LEGMC conducts continuous (i.a. surface water status) monitoring, assesses quantitative status of water bodies and human activity impact on it, submits proposals for water protection purposes, relating to quantitative status of water bodies, and proposals concerning the assignment of water bodies to a risk group in respect of quantitative 
status. Institutions responsible for measures implementation in practice are: Ministry of Environment, Ministry of Agriculture, Ministry of Health, municipalities etc.

Advisory Board for the Daugava area has been established in 2006. There are 15 members in it, representing governmental bodies, municipal (development boards of the planning regions) and non-governmental organizations [10].

Primary river basin authorities - MoEn and LEGMC are active on a national level.

With administrative and economic changes revision of the existing plans may be important.

Authorities and coordinating bodies in other countries under review are similar just with some peculiarities. River basin management in Denmark (after administrative reform), Latvia and Lithuania is arranged on the national level, in Poland, Germany and Sweden on the regional or local level, in Finland mainly on the national level but the regions have had a leeway to adapt the national guidance documents to their circumstances. Reporting on the RBDM is always done on the national level. Generally the national Ministries of the Environment are involved in overall water management as the main competent authorities, certain agencies under their supervision enabling practical measures and committees, boards or councils acting as coordinating bodies.

In Poland practical tasks pertains to the National Water Management Authority and National Committees and Working Groups are involved as coordinating bodies [11]; in Lithuania Environmental Protection Agency was assigned as competent authority responsible for RBD administration [12]; in the Oder RBD International Commission on the Protection of the Oder against Pollution (abbreviated as ICPO) is assigned as an international coordination body (between Germany, Poland, and Czech Republic), while the cooperation and coordination of WFD implementation between the three German federal states in the Oder river basin (Saxony, Brandenburg, Mecklenburg-West-Pomerania) is headed by the federal state of Brandenburg [13]; in Denmark the present implementation structure is considerably more centralised than the structure before the local government reform when 14 county governments were responsible for drawing up the river basin management plans [14]; in Finland, the issues related to water quantity belong to the Ministry of Agriculture and Forestry (MoAF) supervising river basin planning within their fields of activities and having assigned the task to prepare national guidance documents on RBM planning to the Finnish Environment Institute (SYKE), which is Finland's national Center for environmental research and development [15]; in Sweden on the national level the Swedish Environmental Protection Agency and the Geological Survey of Sweden guide the River Basin District Authorities i.a. by creating regulations and guidelines.

\section{Methods used for reaching stakeholders and citizens}

In the course of the planning cycle of public consultation for development of the RBMP in all the countries under review, a variety of tools to inform the public and interested groups and to collect comments and opinions were used. These included: surveys; thematic brochures; guidebooks; leaflets and handouts; articles in the national, regional and industry press; media (information, advertisements provided in the press, radio and television); films; Internet web sites and online maps; meetings; seminars for the main stakeholders groups; debates; panel discussions; press conferences; fora; interviews with key actors; training. Some variations are observed in Sweden where the social network of the representatives is used as an additional way to reach stakeholders [16]; in Lithuania where Environmental Protection Agency has signed agreements with 6 NGOs working in water sector, who became information centers for implementation of the WFD and RBM plans [17]; in Finland a feedback questionnaire done by Finnish Environment Institute for the regional river basin planners about the first RBM planning process [18]. 


\section{Potential areas of concern}

Some countries have experienced certain disagreements between key players during negotiations and discussions on the RBDMP. In Sweden the most important conflict of interests in the Water Basin District of Bottenviken and its Water Councils is on hydropower. Existing hydropower plants and a potential extension of hydropower plants are also in line with the Directive 2009/28/EC of the European Parliament and of the Council of 23 April 2009 on the promotion of the use of energy from renewable sources. An extension of hydropower in Sweden is however in conflict with the WFD. This conflict is evident for many of the rivers in the District, even the minor ones [19]. In Lithuania agriculture and energy sectors were the main stakeholder groups which had expressed their interests. It was rather complicated to reconcile interests of water management with those of agriculture and energy sector [20]. In Finland conflicting views in the planning process concerned, according to the interviewees, mainly hydropower-related issues. The stakeholders could be divided into few groups based on their main interests: interest groups (hydropower producers, agriculture, forestry, peat production); recreational users and NGO's (fishing, nature conservation); authorities (municipalities, regional councils) [21].

Also for the above issues are potential areas of concern in the future. In addition to the said, for Latvia the Daugava river basin is of transnational nature and shared not only with the EU partners as Estonia and Lithuania, but also with non-EU countries Belarus and Russia. Therefore significant mutual efforts aimed at cooperation and inter-state relations are of vital importance.

\section{Conclusions}

1. River basin management in Denmark, Latvia and Lithuania is arranged on the national level, in Poland, Germany and Sweden on the regional or local level, in Finland mainly on the national level but the regions have had a leeway to adapt the national guidance documents to their circumstances. Reporting on the river basin management is always done on the national level.

2. Level of centralization of the river basin management to some extent might be an issue if decisions should be taken as close as possible to the locations where water is affected or used.

3. The WATERPRAXIS Project is linked to implementation of the Water Framework Directive. Legal consequences for activities and differences related to implementation of both can be examined further.

4. In Latvia for successful attainment of goals set by the Daugava river basin district management plan transnational co-operation is important both on the EU level (with Estonia and Lithuania) and via inter-state relations with Russia and Belarus.

5. For successful attainment of goals set by the river basin management possible areas of rivalry and differences between interest groups (energy sector, agriculture, forestry) and recreational users with NGO's (fishing, nature conservation) and authorities (municipalities, regional councils) should be considered.

\section{Acknowledgements}

The article was inspired by the Rezekne Higher Education Institution, Baltic Sea Region Programme 2007-2013 projecte "From theory and plans to eco-efficient and sustainable practices to improve the status of the Baltic Sea - WATERPRAXIS" \#010.

\section{References}

1. Official Journal (OJ L 327), 22 December 2000. Available on http://eur-lex.europa.eu/LexUriServ/ LexUriServ.do?uri=CONSLEG:2000L0060:20090625:LV:HTML (viewed 25.02.2011)

2. http://ec.europa.eu/environment/water/water-framework/info/intro_en.htm (viewed 25.02.2011)

3. http://www.emwis.org/thematicdirs/news/2010/08/eu-river-basin-plan-warning/ (viewed 25.02.2011) 
4. Available on http://waterpraxis.net/ (viewed 25.02.2011)

5. Račys V. WATERPRAXIS: From theory and plans to eco-efficient and sustainable practices to improve the status of the Baltic Sea. Presentation, 2010.

http://www.rfkl.se/Documents/MOMENT/Presentations\%20Water\%20Forum/Waterpraxis.pdf （viewed 25.02.2011)

6. http://waterpraxis.net/downloads/Downloads/Project\%20results/Results $\% 20$ of $\% 20$ Work\%20Package $\% 203 \% 2$ 0WP3/waterpraxis_d3_1a.pdf (viewed 25.02.2011)

7. Daugava River Basin Management Plan, 2010-2015 /in Latvian: Daugavas upju baseina apgabala apsaimniekošanas plāns 2010. - 2015.gadam/, 2009. Available on http://www.meteo.lv/upload_file/ 09_upju_baseinu_apsaimniekosana/2009-12-22/Daugava/VIDMPlan_Daugava.pdf (viewed 25.02.2011)

8. Criteria for selection of River Basin Management Plans for analysis with Waterpraxis. http://waterpraxis.net/downloads/Downloads/Project\%20results/Results\%20of\%20Work\%20Package\%203 \%20WP3/waterpraxis_d3_1a.pdf (viewed 25.02.2011)

9. Reisner R. Competent authorities -introduction and ideas for development. Presentation, 2006. Available on http://www.ccb.se/seminars/documents/ReisnerCA05.pdf (viewed 25.02.2011)

10. Daugava River Basin Management Plan, 2010-2015 /in Latvian: Daugavas upju baseina apgabala apsaimniekošanas plāns 2010.-2015.gadam/, 2009. Available on http://www.meteo.lv/upload_file/ 09_upju_baseinu_apsaimniekosana/2009-12-22/Daugava/VIDMPlan_Daugava.pdf (viewed 25.02.2011)

11. Zabrzeńska-Chaterera M., Imbierowicz S., Skrzypski J., Zbicinski I. Analysis of the Formation System of Management Plans and Water Resources Management. Warsaw, July 2010 (unpublished)

12. Jankūnaitè D., Kliučininkas L. Waterpraxis WP3: Nemunas River Basin District Management plan analysis. Kaunas University of Technology, 2010 (unpublished)

13. „Analysis of the formal structural setup: River Basin Management Plan Oder (area: Germany)”, 2010 (unpublished).

14. Nielsen H. Ø., Pedersen A. B. and Frederiksen P. WP 3 Analysing River Basin Management Project. Case study Denmark - Zealand River Basin District. National Environmental Research Institute, Aarhus University, 2010 (unpublished)

15. Rytkönen A.-M., Saarikoski H., Ulvi T. WP 3 Analysing River Basin Planning Management Processes River Basin Planning in Finland - Case Oulujoki-Iijoki River Basin District. Finnish Environment Institute (SYKE),2010. (unpublished)

16. Results from analyzing River Basin Management Projects, Sweden. (unpublished)

17. Jankūnaitė D., Kliučininkas L. Waterpraxis WP3: Nemunas River Basin District Management plan analysis. Kaunas University of Technology, 2010 (unpublished)

18. Rytkönen A.-M., Saarikoski H., Ulvi T. WP 3 Analysing River Basin Planning Management Processes River Basin Planning in Finland - Case Oulujoki-Iijoki River Basin District. Finnish Environment Institute (SYKE),2010. (unpublished)

19. Results from analyzing River Basin Management Projects, Sweden, 2010. (unpublished)

20. Jankūnaitė D., Kliučininkas L. Waterpraxis WP3: Nemunas River Basin District Management plan analysis. Kaunas University of Technology, 2010 (unpublished)

21. Rytkönen A.-M., Saarikoski H., Ulvi T. WP 3 Analysing River Basin Planning Management Processes River Basin Planning in Finland - Case Oulujoki-Iijoki River Basin District. Finnish Environment Institute (SYKE),2010 (unpublished).

Anotācija. Referātā sniegts ìss pārskats par upju baseinu apsaimniekošanas plāniem Baltijas reǵionā WATERPRAXIS projekta ietvaros, kas ir saistīti ar ES Üdens pamatdirektīvu. Tiek akcentēta Latvijas pieredze upju baseinu rajonu apsaimniekošanas plānu izpildē salīdzinājumāa ar citiem reǵionālajiem partneriem. Raksta pamatā ir pārskata dokumenti, pieejamo datu analīze un izstrādājamo attīstības projektu apskats. Zināmā mērā ieskicētas arō potenciālās apspriežamās problēmas. Dažām Baltijas valstīm ir bijušas grütīioas ES Ūdens pamatdirektīivas ievērošanā, un pastāv dažas potenciālās sāncensības jomas, kuras jānemem vērā turpmākajā darbībā. Administratīvi teritoriālās reformas un citu ES direktīvu (piemēram, atjaunojamās energijias nozarē) izpildī̌sanas gaitā teritoriālajos, $k \bar{a}$ arī upju baseinu apsaimniekošanas plānos un reǵiona ilgtspējīgas attīstības nolūkos var tikt veiktas izmaingas.

Atslēgas vārdi: upju baseinu apsaimniekošanas plāni, Baltijas jūras regions, WATERPRAXIS, sabiedrības lìdzdalība. 